\title{
Dinamika Pranata Sosial Terhadap Kearifan Lokal Masyarakat Nelayan Dalam Melestarikan Wisata Bahari
}

\author{
Lucky Zamzami ${ }^{1}$ \\ Received Article: 28 April 2016 \\ Accepted Article:21 November 2016
}

\begin{abstract}
This article aims to understanding the complexity of social institutions dinamics in the Tiku fishermen with a coast enviroment in the form of management cultural tourism based on local wisdom phenomena. Its problem is contruction the complexity of social institutions with the sea within local wisdom context, belief system, social economic institution. The writer material taken by field work data-interview and observations----related with a study focus and approach choices. Location of research done in the one of villages in west coastal sumatra, is South Tiku Village, Tanjung Mutiara Subdistrict, Agam District. This research shows that a cultural management tourims in Tiku fishermen based on local wisdom characterized by the life of collective (social economy) with strong and neat; pattern of utilization resource reflecting the relationship between subjective relation of human and enviroment; conditions of social economic welfare; maintained of environment preservation and balance of marine resources.
\end{abstract}

Keywords: Social Institutions, Marine Tourism, Local Wisdom, Tiku Fishermen

\begin{abstract}
Abstrak
Tulisan ini bertujuan memahami kompleksitas dinamika pranata sosial nelayan Tiku dengan lingkungan sekitar pesisir dalam wujud pengelolaan budaya wisata bahari berdasarkan fenomena kearifan lokal. Masalahnya adalah mengonstruksi kompleksitas pranata sosial komunitas Nelayan Tiku dengan lingkungan lautnya dalam konteks kearifan lokal, sistem kepercayaan, kelembagaan sosial dan ekonomi. Material penulisan diambil dari data penelitian lapangan-diperoleh dengan wawancara, observasi dan pengamatan-sesuai dengan fokus studi dan pilihan pendekatan. Lokasi penelitian dilakukan di salah satu nagari wilayah pesisir pantai Barat Sumatera, yaitu Nagari Tiku Selatan, Kecamatan Tanjung Mutiara, Kabupaten Agam. Hasil penelitian tersebut menunjukkan bahwa wujud pengelolaan budaya wisata bahari dalam komunitas nelayan Tiku berbasis pada kearifan lokal yang dicirikan dengan tatanan kehidupan kolektif (sosial-ekonomi) yang kuat dan rapi; pola-pola pemanfaatan sumber daya laut yang mencerminkan hubungan antar subjektif manusia dan lingkungan; kondisi kesejahteraan sosial-ekonomi penduduk yang merata; dan terjaganya kondisi kelestarian lingkungan dan keseimbangan sumber daya laut.
\end{abstract}

Kata kunci: pranata sosial, wisata bahari, kearifan lokal, nelayan Tiku.

\footnotetext{
${ }^{1}$ Penulis adalah dosen tetap Jurusan Antropologi FISIP Universitas Andalas 


\section{A. Pendahuluan}

D alam konteks studi antropologi maritim di Indonesia, kajian-kajian tentang masyarakat pesisir terutama komunitas nelayan menjadi perhatian yang serius, terutama mengenai kehidupan sosial budaya dan ekonominya. Sekarang penelitipeneliti antropologi juga memusatkan penelitiannya kepada kajian-kajian pember dayaan sebagai akibat dari dampak pembangunan Indonesia yang dianggap tidak adil dan merata. Dalam konteks ini, kajian tentang pemberdayaan masyarakat nelayan telah memberikan sumbangsih yang berarti bagi dunia antropologi Indonesia, khususnya kajian antropologi kemaritiman. Keunggulan utamanya adalah kajian yang mendalam tentang dinamika pranata sosial yang telah terjalin sekian lama yang dipengaruhi oleh aspek kearifan lokal masyarakat setempat.

Dalam rentang perkembangan penelitian tersebut tentang masyarakat nelayan, bukanlah hal yang baru untuk dibicarakan. Kajian literatur yang cukup luas tentang kehidupan sosial budaya masyarakat nelayan di berbagai tempat di dunia, termasuk Indonesia (lihat antara lain: Lampe, 2007; Firth, 1975; Acheson, 1981; Masyhuri, 1996,) serta melalui riset-riset lapangan, khususnya pada masyarakat nelayan di wilayah pesisir barat Sumatera (Lihat Zamzami, 2010). Hal tersebut telah menunjukkan fenomena sosial budaya yang kompleks, terutama dicirikan pada keberadaan kelompok-kelompok sosial kebaharian seringkali sebagai bagian dari sub-sub komuniti desa pesisir dalam wilayah kesatuan etnik. Seperti berbagai desa-desa nelayan di Indonesia, contohnya Tiku, Laut, Bugis, Mandar, Makassar, Madura di kawasan pesisir dan pulau-pulau bisa relatif merupakan kelompok-kelompok etnik sepenuhnya, seperti desa nelayan Tiku di Sumatera Barat, desa nelayan Bajo di Kepulauan Riau, NTT, Sulawesi Selatan, Sulawesi Tengah dan bahkan suatu negara atau kerajaan, seperti antara lain Kerajaan Goa hingga abad ke-17 (Lampe, 2007). Di Eropa dan negara-negara pantai dan kepulauan maju lainnya selain pelayar, nelayan, pengangkut barang dengan berbagai kategorinya, dan marinir, juga dikenal kelompok-kelompok awak kapal pengeruk dasar sungai dan perairan pantai kota-kota, kelompok-kelompok olah ragawan laut antara lain seperti peselancar dan penyelam, kelompok organisasi pencinta lingkungan laut yang anggota-anggotanya berasal dari kota-kota bahkan dari negaranegara berlainan (Ginkel, 2007; Lampe, 2007).

Secara sosiologis, karakteristik masyarakat nelayan berbeda dengan krakteristik masyarakat petani, seiring dengan perbedaan karakteristik sumber daya yang dihadapi. Masyarakat petani menghadapi sumber daya terkontrol, yakni pengelolaan lahan untuk produksi suatu komoditas dengan output yang relatif bisa diprediksi. Dengan sifat produksi yang demikian memungkinkan tetapnya lokasi produksi sehingga menyebabkan mobilitas usaha yang relatif rendah dan elemen risiko pun tidak besar. Karakteristik tersebut berbeda sama sekali dengan nelayan. Nelayan menghadapi akses sumber daya yang hingga saat ini masih bersifat open access. Karakteristik sumber daya seperti ini menyebabkan nelayan mesti berpindahpindah untuk memperoleh hasil maksimal, yang dengan demikian elemen risiko menjadi sangat tinggi. Kondisi sumber daya yang berisiko tersebut menyebabkan nelayan memiliki karakter keras, tegas, dan terbuka (Satria 2009).

Kompleksitas sosial budaya yang terjadi pada masyarakat nelayan, terutama berkaitan dengan beragamnya kelompok dan kategori sosial terlibat secara langsung atau tidak langsung dalam pemanfaatan sumberdaya dan lingkungan laut serta beragamnya sektor mata pencaharian terkait laut. Fenomena budaya bahari akan mencakup semua fenomena dan untuk pembatasan dan penyederhanaan subjek kajian kiranya dilakukan fokus-fokus studi pada setiap atau beberapa fenomena sosial budaya yang kompleks tersebut. Hal tersebut telah memunculkan dinamika pranata sosial yang sangat mempengaruhi kepada kearifan lokal mereka. Kearifan lokal merupakan strategi adaptasi yang memang muncul dari dalam masyarakat itu sendiri dalam membenahi masalah-masalah sosial yang berkenaan dengan kehidupan masyarakat. Kearifan lokal ini tumbuh dari hasil interaksi antara masyarakat dan lingkungannya.

Keluarnya UU Otonomi Daerah Nomor 32 tahun 2004 membuka peluang untuk pengentasan masalah sosial - yang 
salah satunya adalah kemiskinan. Kewenangan pemerintah daerah menter jemahkan kebijakan nasional dengan menyesuaikan dengan kondisi setempat, termasuk menggunakan kearifan lokal sebagai input penanggulangan kemiskinan di tingkat daerah. Berkaitan dengan kearifan lokal, terdapat lima isu strategis yang perlu diperhatikan dalam pemberdayaan masya rakat nelayan, sebagai input penang gulangan kemiskinan pada tingkat masyarakat, yaitu: (i) Menghormati dan menjunjung tinggi Hak Asasi Manusia, (ii) Komitmen global terhadap pembangunan sosial masyarakat adat sesuai dengan konvensi yang diselenggarakan oleh ILO, (iii) Isu pelestarian lingkungan dan menghindari keterdesakan komunitas asli dari eksploitasi sumberdaya alam yang berlebihan. (iv) Meniadakan marginalisasi masyarakat asli dalam pembangunan nasional, (v) Memperkuat nilai-nilai kearifan masyarakat setempat dengan cara mengintegrasikannya dalam desain kebijakan dan program penanggulangan kemiskinan. Model pemberdayaan masya rakat berbasis kearifan lokal mengandung arti peletakan nilai-nilai setempat sebagai input penanggulangan kemiskinan. Dalam hal ini, kebijakan penanggulangan kemis kinan perlu menempatkan kearifan lokal sebagai input pokok dalam kebijakan penanggulangan kemiskinan. Istilah peleta kan nilai-nilai setempat (kearifan lokal) di sini lebih dimaknai sebagai apresiasi terhadap praktek-praktek penanggulangan kemiski nan yang diinisiasi oleh pelaku-pelaku tingkat lokal dengan menjadikan kebijakan nasional sebagai rambu-rambu dalam membangun kerjasama sinergitas pada berbagai sektor dalam penanggulangan kemiskinan tersebut (Boedhisantoso, 1999).

Model pemberdayaan masyarakat berbasis kearifan lokal mengandung arti peletakan nilai-nilai setempat sebagai input penanggulangan kemiskinan. Setiap masya rakat mempunyai karakteristik sendiri yang belum tentu dimiliki oleh masyarakat lainnya. Nilai budaya yang mereka anut terdiri dari pandangan hidup dan keyakinan, keduanya dibungkus oleh ethos (pedoman etika berkenaan dengan baik dan tidak baik). Kebudayaan adalah sistem pengetahuan yang digunakan oleh manusia untuk membentuk tindakan mereka, dan menginterpretasikan perilaku orang lain
(Spradley, 1979). Salah satu tujuan pemberdayaan masyarakat adalah tercip tanya permbangunan. Paradigma pembangunan yang digunakan adalah (people centre development) yang menem patkan masyarakat sebagai fokus maupun sumber utama pembangunan. Pemba ngunan masyarakat dapat difahami melalui tiga orientasi yaitu: (1) upaya pengadaan pelayanan dasar sebagai kelengkapan dari strategi kebutuhan pokok, diidentikkan dengan peningkatan pelayanan sosial dan pemberian fasilitas sosial, seperti fasilitas kesehatan, peningkatan gizi, pendidikan, dan sanitasi untuk kesejahteraan masya rakat; (2) upaya terencana untuk mencapai tujuan lebih kompleks dan bervariasi, guna mencapai tujuan sosial yang lebih sulit diukur seperti keadilan, pemerataan, peningkatan budaya, kedamaian, serta adanya kesempatan yang sama; dan (3) upaya peningkatan kemampuan manusia untuk berbuat dan meningkatkan postensialitasnya, memobilisasi antusias menya untuk berpartisipasi aktif dalam proses pengambilan keputusan atau kebijakan terkait dengan diri mereka.

\section{B. Kearifan Lokal Masyarakat Nelayan: Jembatan menuju Kemandirian Lokal \\ K earifan lokal adalah kumpulan penge tahuan dan cara berpikir yang berakar dalam kebudayaan suatu kelompok} manusia,yang merupakan hasil pengamatan selama kurun waktu yang lama (Arafah 2002). Sedangkan menurut Adrianto, dkk (2011) kearifan lokal dipahami sebagai usaha manusia dengan menggunakan akal budinya (kognisi) untuk bertindak atau bersikap terhadap sesuatu, objek atau peristiwa yang terjadi dalam ruang tertentu. Pengertian tersebut disusun secara etimologi, dimana wisdom/kearifan difahami seabgai kemampuan seseorang dengan menggunakan akal pikirannya dalam bertindak atau bersikap sebagai hasil penilaian terhadap sesuatu, objek atau peristiwa yang terjadi.

Umumnya kearifan lokal diwujudkan dengan cara tersendiri yang unik dalam norma budaya dalam ritual dan tradisi masyarakat. Aulia (2010) menjelaskan bahwa bentuk-bentuk kearifan lokal yang ada dalam masyarakat dapat berupa: nilai, norma, kepercayaan, dan aturan-aturan 
khusus. Bentuk yang bermacam-macam ini mempengaruhi fungsi kearifan lokal menjadi beragam pula. Kearifan lokal berfungsi untuk konservasi dan pelestarian sumber daya alam, pengembangan sumber daya manusia, pengembangan kebudayaan dan ilmu pengetahuan dan sebagai petuah, kepercayaan, sastra dan pantangan. Semen tara itu dalam memelihara kearifan lokal agar tetap bertahan perlu diperhatikan tantangan-tantangan yang akan dihadapi di masa mendatang, menurut Saharuddin (2009), tantangan-tantangan kearifan lokal adalah pertumbuhan penduduk, teknologi modern dan budaya, modal besar, kemiskinan dan kesenjangan, kesulitan masyarakat dalam memenuhi kebutuhan pokok seringkali menimbulkan masalahmasalah sosial dalam pemanfaatan sumber daya alam.

Kearifan lokal dilihat dari perspektif antropologis untuk memahami eksistensi masyarakat nelayan bertitik tolak dan berorientasi pada hasil hubungan dialektika antara manusia, lingkungan, dan kebudayaannya. Oleh karena itu, dalam beragam lingkungan yang melingkupi kehidupan manusia, satuan sosial yang terbentuk melalui proses demikian akan menmpilkan karakteristik budaya yang berbeda-beda. Orientasi hasil hubungan dialektika manusia tersebut menciptakan suatu tradisi yang dipengaruhi oleh kondisi religi keseharian nelayan dan peran kelembagaan sosial yang berdasarkan budaya lokal berbasis komunitas.

Tradisi bagi masyarakat nelayan dapat dilihat pada masyarakat Jawa dari segi kebudayaan upacara atau ritual adat yang merupakan wujud kegiatan religi atau kepercayaan, melalui tradisi Labuhan di desa Tegalsari Tegal Jawa Tengah (Ken, 2012), tradisi Nadran di daerah pesisir Indramayu, tradisi ritual adat nelayan Larung Sesaji di pesisir kota Rembang, tradisi ritual Petik Laut di Sendang Biru, Malang dan tradisi Tabuik di kota Pariaman. Sebagian besar tradisi sebagai wujud kegiatan religi selalu berkaitan erat dengan ritual sakral dengan tujuan untuk mendapatkan keselamatan dan berkah dari Allah agar dapat memperoleh hasil tangkapan ikan yang berlimpah, membersihkan lingkungan tempat tinggal dan lautan dari sesuatu yang dipandang tidak baik atau buruk serta jahat.
Propinsi Sumatera Barat sebagai salah satu propinsi yang berada di pesisir Barat pulau Sumatera yang memiliki potensi penangkapan dan pengelolaan ikan di laut yang sangat besar sepanjang $375 \mathrm{~km}$, tidak terlepas dari adanya hasil hubungan dialektika masyarakat nelayan yang telah menciptakan tradisi- tradisi yang merupakan wujud kegiatan religi atau kepercayaan melalui peran kelembagaan sosial yang berdasarkan budaya lokal berbasis komunitas pada nelayan tersebut.

Salah satu daerah yang menjadi sentral nelayan dan usaha kelautan di Sumatra Barat selain daripada Kabupaten Pesisir Selatan, Kota Padang, Kabupaten Padang Pariaman dan Kabupaten Pasaman Barat adalah Kabupaten Agam, tepatnya di Kecamatan Tanjung Mutiara. Kecamatan Tanjung Mutiara merupakan satu dari 16 kecamatan di Kabupaten Agam yang memiliki panjang pantai sekitar $43 \mathrm{~km}, 27$ km per segi terumbu karang dan 65 hektare hutan Manggrov. Jumlah Nelayan di kecamatan Tanjung Mutiara tercatat sekitar 1.952 orang dan aktif sekitar 1.750 orang dengan produksi ikan mencapai 3.415 ton/tahun dengan hasil tangkap jenis pelagis, udang dan teri.

Masyarakat nelayan di daerah ini terpusat di nagari Tiku Selatan dan nagari Tiku V Jorong. Kedua nagari tersebut merupakan kawasan pemukiman nelayan yang memiliki konstruksi masyarakat nelayan dalam konteks bahwa masyarakatnya sangat dipengaruhi secara signifikan oleh eksistensi kelompokkelompok sosial yang menciptakan tradisitradisi sebagai perwujudan kegiatan religi melalui peran kelembagaan sosial yang dibentuk berdasarkan budaya lokal masyarakat tersebut. Kelompok-kelompok nelayan yang ada di nagari Tiku Selatan saat ini berjumlah 21 kelompok nelayan. Dari 21 kelompok nelayan tersebut, diantaranya 13 kelompok yang berasal dari perikanan tangkap, sedangkan untuk 8 kelompok perikanan budidaya.

Dalam rangka mengatasi masalah yang dihadapi nelayan tersebut, maka sejak tahun 2001-2008, pemerintah telah mencanangkan suatu program yang diupayakan dapat langsung menyentuh kepentingan masyarakat nelayan, terutama nelayan tradisional yang berorientasi kepada pertumbuhan ekonomi. Di samping 
bertujuan untuk meningkatkan kesejah teraan masyarakat nelayan, juga bertujuan untuk mendidik agar nelayan lebih mandiri dan mempunyai kemampuan untuk hidup lebih baik dalam memanfaatkan sumber daya yang ada secara optimal dan berkelanjutan. Melalui program pemerintah melalui program pemberdayaan ekonomi masyarakat pesisir (PEMP), tetap memperhatikan nilai budaya (tradisi) dan wujud religi melalui peran kelembagaan yang tumbuh dan berkembang dalam masyarakat lokal, sehingga program yang ada tersebut diharapkan dapat mening katkan partisipasi masyarakat dalam pengambilan keputusan dan pengawasan pengelolaan sumber daya laut dan daerah pesisir (Zamzami, 2010:114).

\section{Selama proses pelaksanaan} program pemberdayaan masyarakat tersebut, masyarakat nelayan mengem bangkan kemandirian lokal yang berdasarkan kepada nilai-nilai kearifan lokal sehingga setiap program pemerintah yang masuk ke wilayahnya dapat ditampung melalui suatu pranata sosial yang telah terbentuk tersebut. Keberadaan pranata sosial dalam masyarakat nelayan mampu mewujudkan rasa saling tolong menolong dan toleransi diantara kelompok-kelompok nelayan yang setiap tahunnya terbentuk dengan sendirinya. Pranata sosial yang terwujud dalam suatu lembaga sosial diartikan sebagai "norma lama" atau aturan-aturan sosial yang telah berkembang secara tradisional dan terbangun atas budaya lokal sebagai komponen dan pedoman pada beberapa jenis/tingkatan lembaga sosial yang saling berinteraksi dalam memenuhi kebutuhan pokok masyarakat untuk mempertahankan nilai. Norma lama yang dimaksud yaitu aturanaturan sosial yang merupakan bagian dari lembaga sosial dan simbolisasi yang mengatur kepentingan masyarakat di masa lalu (Sallatang, 1982).

Selain adanya program pemberdayaan yang dilaksanakan oleh pemerintah, salah satu sarana untuk memberikan perlindungan pada masya rakat nelayan adalah membekali me reka dengan pengetahuan akan arti penting hidup berkelompok Pada masya rakat nelayan, pola hidup berkelompok sebenarnya sudah lama dikenal, namun aktivitas mereka belum banyak yang mengarah pada pengangkatan sosial ekonomi mereka. Menyadari akan hal terse but, pemerintah melaksanakan berbagai kegiatan yaitu pengelolaan yang berbasis masyarakat. Pengelolaan yang berbasis pada masyarakat oleh pemerintah sebenarnya sudah pernah dilakukan. Namun pengelolaan itu, lebih banyak berdimensi politik daripada sosial, ekonomi, dan budaya lokal dikarenakan sifat pengelolaannya bersifat top-down. Sebagai contoh; pembentukan LMD (BPD), LKMD, Karang Taruna, Dasa Wisma, Pos Yandu dan lainnya. Lembaga-lembaga ini sebagian kurang berfungsi dalam melaksanakan tugasnya, dan mereka tidak lebih hanya sekedar penghias nama di Kantor-kantor desa.

Tulisan ini dilaksanakan melalui studi lapangan yang bertipe deskriptif dengan pendekatan kualitatif (Newman 1997; Danim, 2002; Vredenbregt 1983). Menurut Bogdan dan Taylor, penelitian kualitatif adalah prosedur penelitian yang menghasilkan data deskriptif berupa data tertulis dan lisan dari orang dan perilaku yang dapat diamati dari lingkungan yang alamiah (Moleong, 2001). Data dalam bentuk wawancara untuk setiap informan dilakukan dengan menggunakan metode snowball (bola salju).

\section{Nelayan Tiku di Sumatera Barat: Gambaran Wilayah dan Kehidupannya}

\section{Gambaran Wilayah Nagari Tiku} Selatan

Wecamatan Selatan terletak di - Kabupaten Agam, Sumatera Barat. Nagari Tiku Selatan terdiri dari 7 jorong, yang terdiri: (1) Jorong Gasan Kaciak dengan luas wilayah $1.141 \mathrm{Ha}$; (2) Jorong Banda Gadang dengan luas wilayah 724 $\mathrm{Ha}$; (3) Jorong Pasa Tiku dengan luas wilayah $111 \mathrm{Ha}$; (4) Jorong Pasia Tiku dengan luas wilayah $100 \mathrm{Ha}$; (5) Jorong Kampung Darek dengan luas wilayah 520 $\mathrm{Ha}$; (6) Jorong Pasia Paneh dengan luas wilayah $605 \mathrm{Ha}$; dan (7) Jorong Sungai Nibuang dengan luas wilayah $385 \mathrm{Ha}$.

Jumlah jorong yang berada di daerah pesisir sebanyak 4 buah (21\%) dan jorong bukan pesisir sebanyak 15 buah (79\%), dengan jumlah penduduk pesisir 
dengan mata pencaharian sebagai nelayan sebanyak 2.152 KK (2\%). Nagari Tiku Selatan berbatasan sebelah utara dengan Nagari Tiku V Jorong, sebelah Selatan dengan Nagari Batang Gasan, sebelah Barat berbatasan dengan Samudra Indonesia dan sebelah Timur berbatasan dengan Nagari Tiku Utara. Nagari Tiku Selatan memiliki ketinggian tempat berkisar $2 \mathrm{~m}$ dari permukaan laut dengan suhu ratarata sekitar $26^{\circ} \mathrm{C}-30^{\circ} \mathrm{C}$ dengan rata-rata curah hujan $2000 \mathrm{~mm}$. Wilayah ini terdiri dari dataran rendah, dengan tinggi pesisir pantai yang rendah. Berdasarkan peng gunaan lahan dan luas wilayah menjelaskan bahwa penggunaan lahan perumahan dan lahan persawahan yang memiliki aliran irigasi mendominasi luas wilayah di Nagari Tiku Selatan, Kecamatan Tiku Selatan, Kabupaten Agam. Nagari Tiku Selatan memiliki garis pantai yang cukup panjang dan juga memiliki keindahan dari aspek pemandangan lautnya.

Pola pemukiman Nagari Tiku Selatan yang mengikuti garis pantai dimulai dari Jorong Gasan Kaciak , kemudian dilanjutkan menuju Jorong Banda Gadang, Jorong Pasa Tiku dan Jorong Pasia Tiku. Untuk 3 jorong lainnya berada di sepanjang perbukitan yang berada di seberang garis pantai. Untuk menuju Nagari Tiku Selatan, dapat ditempuh dengan kendaraan beroda dua dan empat dengan sarana jalan yang cukup baik sehingga dapat ditempuh selama 1.5 jam perjalanan dari ibu kota Sumatera Barat, yaitu kota Padang.

\section{Kemandirian Lokal Nelayan Tiku: Kondisi Saat Ini}

longes ndonesia sebagai negara maritim terbesar di dunia Internasional memiliki potensi yang sangat besar dalam memanfaatkan kekayaan lautnya. Selain itu, Indonesia juga dapat mengambil keuntungan dari wisata bahari laut Indonesia sebagai penambah devisa negara. Potensi kelautan Indonesia yang sangat besar ini seharusnya dapat memberikan hasil yang luar biasa bagi kemakmuran dan kesejahteraan masyarakat nelayan. Sayangnya potensi besar yang dimiliki ini masih belum dimanfaatkan dengan semaksimal mungkin akibat kurangnya kesadaran dan usaha dari berbagai pihak, baik pemerintah maupun masyarakat sendiri dalam pemanfaatan laut Indonesia.

bisa memana Indonesia masih belum kelautannya dengan baik?. Faktor utama yang menjadikan Indonesia masih belum dapat memanfaatkan lautnya dengan baik adalah masih rendahnya sumber daya manusia yang ada. Perhatian pemerintah terhadap pengembangan pembangunan sektor kelautan masih belum maksimal. Namun, dengan pemerintahan baru di era JOKOWI saat ini yang lebih mengedepankan visi kemaritimannya, kita berharap pemerintah dapat bekerja maksimal dan mencapai hasil yang maksimal pula sehingga dapat menangani berbagai masalah ekonomi yang dialami oleh bangsa ini.

Usaha bantuan-bantuan yang dilakukan pemerintah selama ini masih bersifat top down, yang outputnya dinikmati oleh nelayan-nelayan kaya dan nelayan buruh tetap terkungkung dalam garis kemiskinan sehingga apa yang kita harapkan kepada mereka agar mandiri tidak tercapai. Pada hakekatnya usaha untuk mandiri bukanlah bersifat absolut, tetapi bernuansa interkoneksitas dan bersifat komplementaris. Kemandirian itu hanya akan bermakna dan berarti jika dapat dimanfaatkan dan memanfaatkan keman dirian yang dimiliki dan dikembangkan. Peran pemerintah seyogyanya bergeser, demi untuk memberikan porsi yang lebih besar kepada tingkat kemandirian masyarakat. Bukan saja peran dalam pengendalian dan pengaturan, pelayanan masyarakat dan agen pembaharuan, tetapi ditambah dengan peran baru, yaitu pemberdayaan agar kemandirian lokal dalam masyarakat nelayan benar-benar terbentuk demi melepaskan sedikit demi sedikit budaya kemiskinan di tengah mereka. Dengan paradigma pembangunan selama ini, maka peran pemerintah yang selama ini sangat dominan berfungsi sebagai sutradara sekaligus aktor dalam semua kegiatan pembangunan bergeser menjadi pemberdaya dan fasilitator, dalam arti kegiatan pemerintah dialihkan kepada upaya-upaya untuk membuat tatanan mampu membangun dan mengembangkan masyarakat nelayan secara mandiri.

Kemandirian lokal pada masyarakat nelayan wajib terbentuk dalam kehidupan 
nelayan itu sendiri sehingga tidak selalu terpaku oleh bantuan-bantuan pemerintah selama ini. Kemandirian lokal sebagai bagian dari pemberdayaan berkorelasi dengan peran kearifan lokal masyarakat setempat sehingga kesejahteraan masyara kat akan terpenuhi. Dengan bantuan lembaga-lembaga sosial, baik bersifat sosial maupun keagamaan yang terbentuk di tengah kehidupan mereka, maka nilai-nilai kemandirian yang ditopang dengan kearifan lokal mampu menjadikan desa nelayan akan lebih mandiri tanpa bantuan kekuasaan yang masih bersifat top down tersebut.

Kemandirian dan kearifan lokal adalah dua sisi kehidupan yang saling mempengaruhi antara satu dengan yang lainnya. Dikaitkan dengan kondisi masyarakat nelayan saat ini, kemandirian lokal sebagai suatu alternatif pendekatan atau paradigma baru untuk pembangunan wilayah pesisir di Indonesia yang bertitik tolak akibat kegagalan pendekatan pembangunan yang selama ini telah dilaksanakan. Kemandirian yang dipenga ruhi oleh kearifan lokal masyarakat nelayan adalah mesti untuk dilaksanakan. Kemandirian lokal juga mengisyaratkan agar pemberdayaan masyarakat menjadi suatu tatanan yang teratur dan sistematis. Pendekatan kemandirian lokal mengisya ratkan agar semua tahapan pemberdayaan dilakukan secara terdesentralisasi, bukanlan lagi berciri sentralistis karena tidak akan mampu menemukenali karakteristik khas tatanan masyarakat yang ada dan cenderung mengabaikan potensi khas masyarakat tersebut.

Untuk mewujudkan suatu desa yang lebih mandiri di Indonesia melalui pendekatan kemandirian lokal dapat menyatukan tujuan demi masa depan bangsa yang lebih matang dalam pembangunan kelautan Indonesia. Kita sebagai generasi muda harus lebih semangat untuk memberikan langkah nyata dalam memberdayakan masyarakat nelayan, agar mereka menjadi lebih mandiri dan sejahtera. Kita tidak hanya akan menjadi negara berkembang dan bahkan kita juga dapat menyaingi negara maju lainnya di dunia internasional. Namun yang lebih utama adalah kita dapat memajukan kesejahteraan nelayan itu sendiri.

Masyarakat nagari Tiku Selatan menganut sistem kekerabatan matrilineal, yakni kekerabatan mengacu kepada garis keturunan perempuan. Tradisi sosial yang paling unik di nagari ini adalah tradisi perkawinan dan kematian. Tradisi perkawi nan adalah perempuan 'membeli' laki-laki, artinya perempuan yang membayar biaya dan mahar perkawinan. Dalam tradisi ini ada konsep uang 'hilang' dan uang 'menjemput'. Uang hilang adalah uang yang digunakan untuk mengganti pengeluaran orangtuanya dalam membesarkan anak lakilakinya baik berupa uang atau barang seperti motor atau mobil. Penggantian uang hilang ini tergantung kepada tingkat pendidikan dan pekerjaan laki-laki tersebut, apabila tinggi pendidikannya maka semakin tinggi uang hilangnya. Untuk uang menjemput adalah uang yang dibayar ketika menjemput laki-laki saat pelaksanaan pernikahan, dengan uang menjemput berupa ringgit sebanyak 12 emas. Dalam tradisi perkawinan ini didalamnya terdapat prosesi seperti adat menurunkan pengantin perempuan dari rumah ibunya (bundo kanduang), adanya upacara mencukur rambut, "balatui badia', adat menjemput pengantin laki-laki (bagalombang duo baleh).

Selain tradisi perkawinan, tradisi kematian di wilayah ini terbilang unik. Tradisi kematian disebut dengan istilah 'batagak adat' dengan cara 'Bejamba', yaitu masing-masing keluarga, tetangga dan kerabat dalam satu suku yang melayat membawa makanan yang kemudian ditumpuk-tumpuk menjadi sebuah gunung makanan hingga mencapai lebih kurang 2 meter. Setelah makanan menggunung, maka dilaksanakan acara berdoa (zikir) bersama, setelah itu dilakukan kegiatan membagi-bagi harta warisan, "malewang gala", upacara doa setelah 3, 7, 14, 40 dan 100 hari kematian anggota keluarga.

Ekonomi perikanan yang dilakukan oleh nelayan pada umumnya dilakukan secara berkelompok tetapi ada juga yang melakukannya secara perorangan. Kegiatan tersebut sebagian besar dilakukan oleh pihak laki-laki yang berumur diatas 15 tahun. Pendapatan nelayan di nagari Tiku Selatan berkisar antara Rp.25.000,- hingga Rp. 100.000,-. Pendapatan nelayan termasuk rendah dikarenakan sebagian besar nelayan di nagari Tiku Selatan tersebut adalah nelayan buruh (60\%). Aktivitas penangkapan ikan pada 
masyarakat nelayan Nagari Tiku Selatan, yaitu aktivitas membagan, memayang, memukat dan menjaring. Teknologi pada penangkapan ikan menjaring menggunakan peralatan jaring dan perahu. Jaring yang selalu dipergunakan oleh masyarakat nelayan Nagari Tiku Selatan adalah yang berukuran 100-200 m. Jaring ini ada yang jahitannya halus dan kasar. Jaring yang halus ukuran matanya memiliki panjang 25$20 \mathrm{~cm}$ dan lebarnya kira-kira $5 \mathrm{~cm}$, sedangkan jaring yang jahitannya kasar ukuran matanya memiliki panjang 50-60 cm dan lebar $10 \mathrm{~cm}$. Untuk jahitan yang kasar adalah untuk menangkap ikan yang besarbesar seperti ikan gembolo, ikan gurigak, belatuk dan soaso, sedangkan jahitan yang halus atau rapat adalah untuk menangkap ikan yang kecil-kecil seperti ikan campu, pinang-pinang, maco dan tete. Untuk menangkap ikan dengan menjaring mempergunakan sebuah perahu yang panjangnya lebih kurang $4 \mathrm{~m}$ dan lebarnya 1 $\mathrm{m}$. Perahu yang banyak digunakan oleh masyarakat nelayan Nagari Tiku Selatan saat ini sudah banyak memakai mesin perahu/mesin tempel.

Hasil tangkapan ikan yang diperoleh langsung di bawa ke pasar tradisional Tiku Selatan dan disana sudah ada agen atau pembeli yang menanti. Biasanya agen-agen tersebut telah ditentukan oleh induk semang. Alasan lain nelayan menjual ikan di pasar tradisional Tiku Selatan karena semua jenis ikan dapat diterima baik besar maupun kecil, begitu juga dengan jenis-jenisnya.

Nagari Tiku Selatan merupakan Nagari yang memiliki potensi sumber daya alam yang cukup banyak dilihat dari berbagai aspek seperti Nagari Tiku Selatan mempunyai wilayah laut yang dengan garis pantai sepanjang $\pm 6 \mathrm{~km}$ dan disertai dengan Tempat Pendaratan Ikan (TPI) beserta fasilitas penunjang lainnya. Potensi hasil laut nagari Tiku Selatan telah menjadi salah satu andalan ekonomi yang utama dari nagari Tiku Selatan.

Dari segi infrastruktur dan perhu bungan Nagari Tiku Selatan dilalui oleh jalan negara yang menghubungkan Ibukota Propinsi dan lbukota Kabupaten. Ditambah dengan beradanya ibukota Kecamatan Tanjung Mutiara di Nagari Tiku Selatan, maka hampir seluruh kantor instansi pemerintah dan swasta serta sekolahsekolah berada di Nagari Tiku Selatan. Dari Segi Ekonomi otomatis dengan keberadaan TPI dan pasar serikat, maka seluruh aktifitas utama perikanan dan ekonomi berada di Nagari Tiku Selatan. Ditambah dengan keberadaan kantor beberapa Bank BPR dan bank umum, Koppem serta BMT yang terletak di Nagari Tiku Selatan yang sangat membantu pertumbuhan ekonomi masyarakat. Dari segi sumber daya manusia Nagari Tiku Selatan mempunyai asset SDM yang cukup banyak dengan tingkat pendidikan yang cukup tinggi serta mempunyai beragam keahlian. Namun potensi tersebut belum tergali dan dimanfaatkan secara maksimal

\section{Peran Pranata Sosial dalam Pengembangan Kawasan Wisata Bahari}

ejalan dengan program pemerintahan
JOKOWI-JK saat ini, yaitu
"Menjadikan Indonesia menjadi poros maritim dunia" yaitu dengan meningkatkan penguatan pembangunan maritim yang diiringi dengan menguatnya tuntutan demokratisasi dan peningkatan peranan masyarakat (stakeholders), pemerataan dan keadilan serta perhatian terhadap potensi laut dan keanekaragaman daerah, maka proses pengembangan kawasan pesisir dan laut hendaknya disusun dalam bingkai pendekatan integralistik yang sinergistik dan harmonis, dengan memperhatikan sistem nilai dan kelembagaan yang tumbuh dan berkembang dalam masyarakat setempat serta sejalan dengan pengembangan sumber-sumber potensi lokal dan kearifan lokal.

Melalui pembangunan poros maritim dengan mengembangkan wisata bahari di Indonesia harus memanfaatkan Indonesia sebagai Negara Maritim. Potensi maritim ini memiliki prospek besar, salah satunya dalam wisata bahari, sehingga sangat menguntungkan kedepan apabila pariwisata bahari di Indonesia dapat dikembangkan dengan baik dan professional. Pada tahun 2007, Provinsi Sumatera Barat oleh Departemen Kebudayaan dan Pariwisata telah ditetapkan salah satu dari lima daerah di Indonesia yang dijadikan sebagai daerah destinasi unggulan serta menawarkan 
Mentawai sebagai lokasi selam terbaik Indonesia. Kebijakan ini ditetapkan oleh pemerintah pusat sebagai upaya mengembangkan pariwisata di luar pulau Jawa dan Bali.. Hal ini merupakan kesempatan untuk mengembangkan dan mempromosikan potensi wisata, khususnya wisata bahari atau kawasan pesisir yang terdapat di Sumatera Barat. Kawasan pesisir Sumatera Barat memiliki potensi yang luar biasa dan prospek untuk dikembangkan. Selain kekayaan laut yang masih belum tergarap dengan optimal, kawasan-kawasan ini memiliki objek wisata yang bisa dikembangkan secara luas. Berikut adalah potensi wisata bahari Sumatera Barat.

Pemerintah Kabupaten Agam berupaya mengedepankan wisata bahari setelah melihat potensi yang belum dioptimalkan. Hal ini ditunjukkan dengan keseriusan pemerintah Kabupaten Agam di tahun 2013 untuk membenahi kawasan 3 (tiga) pantai yang berada di Kecamatan Tanjung Mutiara, yaitu pantai Muara Batang Tiku, Pantai Bandar Mutiara dan Pulau Ujung dan Tangah. Kawasan wisata bahari yang berada di Pantai Tiku, Tanjung Mutiara, dengan jumlah nelayan sebanyak 2.780 orang, yang terdiri dari nelayan penuh 1.689 orang dan nelayan sambilan 561 orang. Kawasan pesisir Tiku dikenal sebagai sentra perikanan laut dan merupakan salah satu outlet komoditi unggulan perikanan Kabupaten Agam. Kawasan pesisir Tiku merupakan wilayah yang memiliki potensi daya alam laut dengan garis pantai sepanjang kurang lebih $6 \mathrm{~km}$ yang pemanfaatannya memiliki potensi wisata bahari belum tergali secara maksimal.

Rencana pengembangan kawasan wisata bahari harus dikaitkan dengan pemberdayaan masyarakat pesisir. Masyarakat pesisir adalah masyarakat yang memiliki banyak pengetahuan tentang kondisi obyektif wilayahnya. Oleh karena itu dalam pengembangan kawasan wisata bahari, senantiasa hendaknya di mulai pendekatan terhadap masyarakat setempat sebagai suatu model pendekatan pe rencanaan partisipatif yang menempatkan masyarakat pesisir memungkinkan saling berbagi, meningkatkan dan menganalisa pengetahuan mereka tentang bahari dan kehidupan pesisir, membuat rencana dan bertindak. Pemberdayaan ekonomi masya rakat pesisir melalui pembangunan kawasan wisata bahari di Kawasan pesisir Tiku secara terpadu diyakini sebagai upaya ideal untuk mengatasi persoalan ekonomi, sosial dan ekologi yang ada pada kawasan pesisir tersebut, dengan tidak mengabaikan dimensi-dimensi seperti filosofi pemberdayaan, potensi sosial budaya masyarakat berdasarkan kearifan lokal masyarakat setempat.

Pada komuniti nelayan Tiku, pranata sosial/kelembagaan yang tetap bertahan saat ini, yaitu pranata kekerabatan, pranata agama/kepercayaan dan pranata ekonomi. Bagi komuniti-komuniti bahari, pranata merupakan perangkat-perangkat aturan terpadu dengan organisasi/kelembagaan yang mengatur kegiatan-kegiatan tertentu difungsikan sebagai mekanisme penyesuaian diri dengan lingkungan atau pemecahan masalah-masalah sosial ekonomi yang mendesak, yang dengan demikian menjadi bagian dari dan menandai gaya pengelolaan (management style).

Kelembagaan tradisional yang masih hidup di Nagari Tiku Selatan adalah kelompok sosial pengajian, arisan ibu-ibu dan yasinan, masih berjalan dengan baik. Partisipasi rumah tangga terhadap kelompok sosial juga sangat baik. Hampir seluruh ibu-ibu terlibat dalam kegiatan rutin kelompok tersebut. Pengajian dan yasinan dilaksanakan setiap minggu secara bergilir dari rumah ke rumah. Sedangkan arisan dilaksanakan setiap dua minggu. Strategi sosial dilakukan dengan jalan memanfaatkan ikatan-ikatan sosial yang ada di perdesaan baik berupa lembaga kesejahteraan lokal, hubungan produksi hingga jejaring sosial berbasis kekerabatan atau pertemanan. Melalui peran kelembagaan sosial dianggap mampu melestarikan tradisi-tradisi yang sejak lama dilakukan di nelayan Tiku. Mereka menjalankan kegiatan tradisi yang didukung dengan aktivitas untuk mempererat tali silaturahmi dan membantu diantara mereka. Apabila salah satu anggota rumah tangga mengalama kesulitan maka dia akan dibantu melalui peran kelembagaan sosial tersebut.

\section{E. Kesimpulan}

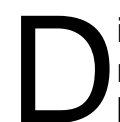
inamika pranata sosial mampu memberikan kekuatan yang positif bagi nelayandalam kehidupan keseharian mereka. Pranata sosial 
perikanan dalam hal ini mampu mem berikan jawaban atas permasalahan di atas. Penguatan kelompok sosial nelayan melalui kelembagaan sosial merupakan suatu kebutuhan yang sangat mendesak dan mutlak diperlukan oleh nelayan, agar mereka dapat bersaing dalam melak sanakan kegiatan usaha perikanan dan dapat meningkatkan kesejahteraan hidup nya. Pranata sosial mempunyai peran yang penting dalam melestarikan tradisi-tradisi yang telah terbentuk sejak lama. Tradisi yang turun temurun mampu meningkatkan pengembangan masyarakat nelayan terutama kepada aspek kekerabatan dan ikatan emosional sesama nelayan.

Pengembangan masyarakat nela yan melalui penguatan pranata sosial perikanan merupakan suatu upaya pemberdayaan terencana yang dilakukan secara sadar dan sungguh-sungguh melalui usaha bersama nelayan untuk memperbaiki keragaman sistem perekonomian masya rakat pedesaan. Arah pemberdayaan nelayan akan disesuaikan dengan kesepa katan yang telah dirumuskan bersama. Dengan partisipasi yang tinggi terhadap kelembagaan nelayan, diharapkan rasa ikut memiliki dari masyarakat atas semua kegiatan yang dilaksanakan akan juga tinggi. Keberhasilan penerapan suatu pranata sosial nelayan tidak semata-mata diukur dengan nilai tambah ekonomi, namun harus mempertimbangkan peran dan fungsi nilai-nilai sosio-kultural secara utuh.

\section{Daftar Pustaka}

Acheson, James M. (1981). "Anthropology of Fishing". Annual Review Anthropology Inc. Vol. 10. P 275-316

Adrianto L, Amin MAA, Solihin A, Hartoto DI. 2011. Konstruksi Lokal Pengelolaan Sumberdaya Perikanan di Indonesia. Bogor (ID): IPB Press.

Arafah, N. 2002. Pengetahuan Lokal Suku Moronene dalam Sistem Pertanian di Sulawesi Tenggara. Program Pascarasarjana Institut Pertanian Bogor.

Aulia TOS, Dharmawan AH. 2010. Kearifan lokal dalam pengelolaan sumber daya air di Kampung Kuta. Sodality. 4(2010):335-346.

Boedhisantoso, S.(1999). Komunitas Lokal di Kawasan Pesisir dan Pemberdayaannya. Makalah Lokakarya Pembangunan Pranata Sosial Komunitas pesisir. Depok $30 \mathrm{Mei}-1$ juni 1999

Bungin, Burhan, 2004, Metodologi Penelitian Kualitatif:Aktualisasi Metodologis ke Arah Ragam Varian Kontemporer, Jakarta: PT. RajaGrafindo Persada.

Cohen, A. P. 1985. The Symbolic Construction of Community London: Tavistock

Danim, Sudarwan, 2002, Menjadi Peneliti Kualitatif, Bandung: Pustaka Setia.

Elfindri, Rumengan J, Bachrum S. 2009. Manajemen Pembangunan Kepulauan dan Pesisir. Jakarta (ID): Baduose Media.

Fauzi A. 2004. Ekonomi Sumber Daya Alam dan Lingkungan: Teori dan Aplikasi. Jakarta (ID): Pustaka Utama.

Frazer, E. 1999. The Problem of Communitarian Politics: Unity and Conflict. Oxford: Oxford University Press.

Firth, 1975, Malay Fishermen: Their Peasant Economy, W. W. Norton \& Company; Second Edition edition (July 17, 1975)

Ginkel, Rob van. 2007. Coastal Cultures: An Anthropology of Fishing and Whaling Traditions. Apeldoorn: Het Spinhuis Publishers

Keesing, Roger M. 1989. Antropologi Budaya: Suatu Perspektif Kontemporer. Jakarta: Erlangga

Ken, Widyatwati, 2012, Tradisi Labuhan Bagi Masyarakat Nelayan Tegalsari Tegal. Alayasastra Jurnal IImiah Kesusastraan Vol. 8 Nomor 1, Semarang Mei 2012. , 8 (1). pp. 1-19.

Kluckhon, Clyde 1984. "Cermin bagi Manusia", dalam Parsudi Suparlan (Ed.). Manusia, Kebudayaan, dan Lingkungannya. Jakarta: Rajawali Pers.

Koentjaraningrat. 1987. Kebudayaan Mentalitas dan Pembangunan. Jakarta: PT Gramedia Kusnadi. 2000. Nelayan: Strategi Adaptasi dan Jaringan Sosial. Bandung: Humaniora Utama Press. 
2001. Pangamba' Kaum Perempuan Fenomenal: Pelopor dan Penggerak Perekonomian Masyarakat Nelayan. Bandung: Humaniora Utama Press. . 2003. Akar Kemiskinan Nelayan. Yogyakarta: LKiS. 2009. Keberdayaan Nelayan dan Dinamika Ekonomi Pesisir. Yogyakarta: Ar- Ruzz Media. .2010. "Kebudayaan Masyarakat Nelayan" dalam Makalah ini disampaikan dalam kegiatan JELAJAH BUDAYA TAHUN 2010, dengan tema "Ekspresi Budaya Masyarakat Nelayan di Pantai Utara Jawa", yang Diselenggarakan oleh Balai Pelestarian Sejarah dan Nilai Tradisional, Kementeian Kebudayaan dan Pariwisata, di Yogyakarta, tanggal 12-15 Juli

Kusnadi. 2006. Filosopi Pemberdayaan Masyarakat Pesisir. Bandung: Humaniora. 2010.

Kordi K, Ghufran MH. 2015. Pengelolaan Perikanan Indonesia: Catatan Mengenai Potensi, Permasalahan, dan Prospeknya. Yogyakarta (ID): Pustaka Baru Press.

Lampe, Munsi, 2007, "Budaya bahari dalam konteks global dan modern: kasus komunitaskomunitas nelayan di Indonesia" dalam Walasuji: jurnal budaya Sulselra \& Barat, Balai Kajian Sejarah dan Nilai Tradisional Makassar.

Mallawa A. 2006. Disajikan pada Lokakarya Agenda Penelitian Program Coremap II Kabupaten Selayar, 9-10 September 2006. Staf Pengajar Fakultas Ilmu Kelautan dan Perikanan Unhas Makassar.

Masyhuri. 1995. Pasang Surut Usaha Perikanan Laut, Tinjauan Sosial Ekonomi Kenelayanan di Jawa dan Madura 1850-1940. Vrije Universiteit Academich Proefschrijft.

Moleong, Lexy, 2001, Metode Penelitian Kualitatif, Bandung: PT.Remaja Rosda Karya.

Neuman, W. Lawrence, 2006, Social Research Methods: Qualitative and Quantitative Approaches $6^{\text {th }}$ Edition, US: Pearson International Edition

Pasaribu LO. 2007. "Kelembagaan Pengelolaan pada Masyarakat Dayak Kenyah di Pampang Kecamatan Samarinda Utara, Kalimantan Timur" [skripsi]. Bogor: Fakultas Kehutanan, Institut Pertanian Bogor

Pranadji T. 2003. Menuju Transformasi Kelembagaan dalam Pembangunan Pertanian dan Pedesaan. Jakarta: Pusat Penelitian dan Pengembangan Sosial Ekonomi Pertanian.

Saharuddin. 2009. Pemberdayaan masyarakat miskin berbasis kearifan lokal. Sodality. 1(April).

Sallatang, Mohammad Arifin. 1982. "Pinggawa Sawi Suatu Studi Sosiologi Kelompok Kecil". Disertasi.Makassar: Universitas Hasanuddin.

Satria A. 2009. Ekologi Politik Nelayan. Yogyakarta (ID): LKiS.

Satria A. 2009. Pesisir dan Laut untuk Rakyat. Bogor (ID): IPB Press.

Satria et al. 2002. Menuju Desentralisasi Kelautan. Jakarta (ID): Cidesindo.

Solikhin, Satria A. 2007. Hak ulayat laut di era otonomi daerah sebagai solusi pengelolaan perikanan berkelanjutan: Kasus awig-awig di Lombok Barat. Sodality. 1(April).

Saharuddin. 2009. Pemberdayaan masyarakat miskin berbasis kearifan lokal. Sodality. 1(April).

Spradley, James. P, 1979, New York: Holt, Rinehart and Winston.

Susilo E. 2010. Dinamika, Struktur Sosial dalam Ekosistem Pesisir. Malang (ID): UB Press.

Vredenbregt. 1983. Metode dan Teknik Penelitian Masyarakat. Jakarta: PT. Gramedia.

Zamzami, Lucky. (2009). "Sistem Pengetahuan Lokal Nelayan Terhadap Teknologi Penangkapan Ikan pada Masyarakat Pasar Laban, Kecamatan Bungus Teluk Kabung, Kota Padang" dalam Jurnal FENOMENA Volume 07, Nomor 02, September 2009

Zamzami, Lucky. (2009). "Studi Kualitatif Dampak Perubahan Sosial terhadap Amalan Merantau di Kalangan Nelayan." Satu Kajian Kes di Kelurahan Purus, Kota Padang: UKM Malaysia: Tesis yang tidak dipublikasikan.

Zamzami, Lucky. 2010. Pemberdayaan Ekonomi Masyarakat Pesisir di Nagari Ampiang Perak, Sumatera Barat dalam Jurnal MIMBAR MIMBAR, Vol. XXVII, No. 1 (Juni 2011): 113-125 Terakreditasi' SK Dikti No. 64a/DIKTI/Kep/2010 